\title{
Susma Söyle: Sokak Müziğinin Onu Performe Eden Genç Yetişkinlerin İletişimsel Eylemlerindeki Rolü
}

\author{
Sümeyra Soydaş \\ Yüksek Lisans Öğrencis \\ Galatasaray Üniversitesi İletişim Fakültesi \\ soydassumeyra@gmail.com \\ ORCID: 0000-0001-8883-3709
}

\begin{abstract}
Don't Be Silent, Sing: The Role of Street Music in The Communicative Action of Young Adult Performers

Music affects the aesthetic experience of the performers and their communicative action. As it is performed in the public sphere, street music makes it possible to examine many aspects of these actions that take place in the mediocrity of daily life. This study aims to explore the role of street music in aesthetic experience and communicative action of the young adult performers with strong focus on such three interactions: relations between performer-listener, among performers, and between performer and their close ones. In this study, it is argued that street music, which is considered in the context of performance, enables many interactions and contributes to the communicative actions of young adult performers. This argument was tested with semi-structured in-depth interviews with young adults who constitute the sample of the study. The experiences of the interviewees were evaluated with the descriptive analysis technique in line with the theoretical/conceptual framework. In the light of both secondary literature review and interviews; it has been concluded that street music contributes positively to socialization and negotiation ethics of young adult performers.
\end{abstract}

keywords: Street music, performance, urban space, public sphere, young adult, communicative action

DOI:10.16878/gsuilet.942964 


\section{Résumé}

\section{Ne soyez pas silencieux, chantez: le rôle de la musique de rue dans l'action communicative de Jeunes interprètes adultes}

La musique affecte l'expérience esthétique des interprètes et leur action communicative. Pratiquée dans l'espace public, la musique de rue permet d'examiner de nombreux aspects de ces actions qui se déroulent dans la médiocrité de la vie quotidienne. Cette étude vise à explorer le rôle de la musique de rue dans l'expérience esthétique et l'action communicative des jeunes interprètes adultes en mettant fortement l'accent sur ces trois interactions: les relations entre interprète-auditeur, parmi les interprètes et entre les interprètes et leurs proches. Dans cette étude, il est avancé que la musique de rue, considérée dans le contexte de la performance, permet de nombreuses interactions et contribue aux actions de communication des jeunes interprètes adultes. Cet argument a été testé avec des entretiens approfondis semi-structurés avec de jeunes adultes qui constituent l'échantillon de l'étude. Les expériences des personnes interrogées ont été évaluées avec la technique d'analyse descriptive conformément au cadre théorique / conceptuel. À la lumière de la revue de la littérature secondaire et des entretiens; il a été conclu que la musique de rue contribue positivement à l'éthique de socialisation et de négociation des jeunes artistes adultes.

mots-clés: Musique de rue, performance, espace urbain, sphère publique, jeune adulte, action communicative

\section{Öz}

Müzik, onu icra edenin estetik deneyimini ve iletişimsel eylemlerini etkilemektedir. Sokak müziği ise kamusal alanda icra edilişiyle, gündelik hayatın aleladeliğinde gerçekleşen bu eylemlerin birçok yönden incelenmesine olanak tanımaktadır. Bu çalışma, sokak müziğinin, onu icra eden genç yetişkinlerin estetik deneyimleri ve iletişimsel eylemlerindeki rolünü; icra eden-dinleyici, icra edenler arası ve icra eden-yakın çevresi arasındaki etkileşimden oluşan sac ayağına odaklanarak keşfetmeyi amaçlamaktadır. Bu çalışmada, performans bağlamında ele alınan sokak müziğinin birçok etkileşime olanak tanıdığı ve onu icra eden genç yetişkinlerin iletişimsel eylemlerine katkı sağladığı iddia edilmektedir. Bu iddia, çalışmanın örneklemini oluşturan genç yetişkinlerle yapılan derinlemesine görüşmeler ile test edilmiştir. Görüşmecilerin deneyimleri kuramsal/kavramsal çerçeve doğrultusunda betimsel analiz tekniğiyle değerlendirilmiştir. Gerek ikincil kaynak taraması gerekse yapılan görüşmeler ışığında; sokak müziğinin onu performe eden genç yetişkinlerin, sosyalleşme ve müzakere etiği süreçlerine olumlu katkı sağladığı sonucuna varılmıştır.

anahtar kelimeler: Sokak müziği, performans, kent mekânı, kamusal alan, genç yetişkin, iletişimsel eylem 


\section{Giriş}

Sokak müziğinin tarih sahnesinde yer alışı birçok kaynağın hem fikir olduğu şekliyle antik Yunan ve Roma kentlerine dayanmaktadır (Rocconi, 2012; Brokett, 2000). Antik Yunan şehirlerinde halka açık meydanlarda sergilenen Yunan tragedyalarına eşlik eden müzik; Schechner'in (2002) tanımladığı şekliyle iki kez davranılan davranış (twice behaved behavior) olarak sergilendiğinden, sokak müziğinin performans bağlamında ilk kez gerçekleştirilişi sayılmaktadır. Günümüz sokak müziğine en yakın hal, bugünün kent düzenine daha yakın bir düzene sahip olması nedeniyle antik Yunan'daki meydanlarda gerçekleştirilen müzik icraları varsayılsa da, Fars, Arap ve Hint topluluklarının yanı sıra Anadolu'da da "aşık" veya "ozan" olarak bilinen gezgin müzisyenler de sokak müziği icra etmekteydi. Nitekim, ozanların bugünün kent meydanıyla ortaklıkları bulunan köy meydanlarında yoğunlukla saz eşliğinde söyledikleri türkü ve deyişler, gerek dinleyici olan köy halkının beğenisini şekillendiren kültürel kodları içermesi ve ona göre icra edilişi; gerek ozanın icrasında farklı birçok insan ile müzik yoluyla etkileşime geçmesiyle sokak müziğinin dinamiklerini barındırıyordu.

Gezgin müzisyenlerin icraları sokak müziğinin bazı niteliklerini taşısa da, sokak müziği kent devrimi ile bugünkü anlamını kazanmıştır. Gündelik yaşama eleştirel bakan Lefebvre'e göre, kent devrimiyle ivme alan kapitalizm artık hayatın her alanına nüfuz ederek gündelik yaşamda kentliliği de olmazsa olmaz kılmıştır (Lefebvre, 1991a, s.16). Günümüz kentlerinin yoğun ve stresli hayatlarına şahitlik eden sokak, cadde ve şehir meydanları sokak müziğiyle hem gündelik hayatın sıradanlığına dahil olmakta, hem de bu sıradanlığı bozmaktadır. Bu anlamda gündelik hayatın birçok dinamiğini barındıran sokak, orada icra edilen müziği duyumsamayı da şekillendirmektedir. Burada icra edilen artık yalnızca şarkı söylemek ve enstrüman çalmaktan ibaret bir müzik aktarımı değil, birçok etkileşime olanak veren ve tekrarlanan haliyle bir performanstır. Sokak müziği, dinleyicinin ne duyacağını bir nebze bilerek biletiyle gittiği bir performans sanatından farklı olarak gündelik yaşamda şehrin ruhunun ve sokağın tüm öznelerinin performansa bir anlamda dahil olduğu yoğun bir etkileşim alanıdır.

Ortak toplumsal etkinlik alanları olan kamusal alanlar, "sokak" olarak genellense de; sahnesi "herkese açık" olan her yerde icra edilen müzik, sokak müziğine dahil edilebilmektedir. Bu çalışmada, modern kentlerde sokak müziği icrasına odaklanıldığı için, 18. yüz yıl itibariyle gelişen kamusalığa dair açıklamalar getiren Habermas'ın kentleşme ve bireyleşme ile paralel olarak yaptığı kamusal alan ve iletişim tartışmaları anlam ifade etmektedir. Zira kentler, donuk ve hissiz mekânlar değildir. Kent mekânı, bireylerin katıımı ve bir aradalığıyla kamusal alan niteliği taşımaktadır (Habermas, 2007, s.135). Kamusal alanlar, herkese açık ve birçok karşılaşmanın ve etkileşimin olduğu, böylece toplumsal birleşmelerin gerçekleştiği mekânlardır (Habermas, 2007, s. 135). Sokak müziği ise kamusal alanda bu etkileşime olanak tanıyan, müziğin bu etkileşimde dil olduğu bir icradır. Peki, rasyonel bireyin toplumsallaşmasında elzem olan iletişim, müzik yoluyla na- 
sıl bir uzlaşı aracı olmaktadır? Sokak müziği, icra edenin müziği duyumsamasının yanı sıra dinleyenlerin müzik yoluyla etkileşimde bulunmasına ne derece olanak tanımaktadır? Sokakta performe edilen müzik, modern kentin olağan bir bileşeninden öteye geçememiş midir? Tüm bu sorular, sokağın ruhu ve etkileşimleri ile okunmasıyla çözümlenebilir. Schechner'in Turner'ın da katkısıyla geliştirdiği performans kuramına göre icra edilenler -eylenenler- performans ile sahnenin ötesine yani gündelik hayata taşınmıştır. Zira gündelik hayatta, her davranışta ve her yerde olan edimsellik (performativity), sanat ve dilde de var olmaktadır (Schechner, 2002, s.110).

Yapılan literatür taramasında sokak müziğinin mekân ile ilişkisini ele alan birçok çalışmaya rastlanmış, bu çalışmaların mekân-sanatçı ilişkisine yoğunlukla kent sosyolojisi perspektifiyle eğildiği fark edilmiştir. Sokak müzisyenlerinin kent mekânı aktörleri ile etkileşimleri, kentteki aktörlere adapte oluş süreçlerinde iletişimlerinin güçlü ve zayıf yönlerini ortaya koymaktadır (Kozyr, 2014, s. 252). Sokak müzisyenlerinin etkileşimlerini ele alan çalışmalar, yoğunlukla müzisyeni ve performansını ait olduğu sınıfıyla ilişkilendirerek irdelemiştir. Bu bağlamda sokak müzisyenlerinin iletişimleri, ait olduğu kimlik ve cemaate göre şekillenmektedir (Kozyr, 2014, s. 252). Iletişim bilimleri bağlamında sokak müziği, müzik teknolojilerini yeniden şekillendirerek kentsel ses ortamına katkı sağlamaktadır (Bennet ve Rogers, 2014). Müziğin gençlerin iletişimindeki rolünü müziği genel anlamda ele alarak irdeleyen çalışmalara göre müzik, yalnızca gençlerin duygu ve düşüncelerini ifade etmesi yönüyle araçsal anlamda okunamaz. Zira, sergilenen müzik performansı ifade etme amacından ayrı düşünülemese de özellikle güncel şarkıların doğrudan araçsal amaçla yazılıp söylendiği çıkarımına varılamaz (Bloodworth, 1975, s.306). Gerek dinleyici gerekse icra edenin duygu ve düşüncelerini ifade

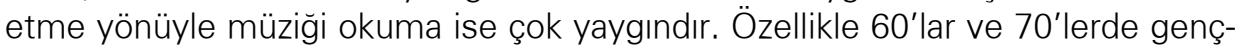
lerin duygu ve düşüncelerini dile getirmede ve tümüyle iletişimsel eylemlerinde müzik önemli bir yere sahiptir (Irvine ve Kirkpatrick, 1972). Bu iletişim, müzisyenin retorik faaliyette bulunmasıyla ritim, kelime ve tempodan oluşan semboller sistemini değiştirmesine olanak vererek dinleyicinin estetik değerlerine karşı etki yaratmaktadır (Bloodworth, 1975, s.309).

Iletişim bilimleri çerçevesinde ise genç yetişkinlerin sokak müziği performansına odaklanan fazla çalışmaya rastlanmamıştır. Sokak müziğini ele alan çaış̧malar, yoğunlukla sosyoloji ve müzikoloji bağlamında gençlerin müzik icralarına odaklanan çalışmalardır. Bu çalışmayı farklı kılan ise, bir eylemliliğin tekrarı söz konusu olduğu için, aynı ritimden olan ancak hayatın olağan akışının dışında kalan sokak müziği icrasının performans bağlamında ele alınmasıdır. Ayrıca bu çalışma, sokak müziği icra eden genç yetişkinlerin estetik deneyiminin yanı sıra iletişimsel eylemlerini sorgulayarak sanat performansına iletişim antropolojisi bağlamında yaklaşmıştır. Vincenzo Cicchelli, genç yetişkinlik tabirini genç ve yetişkin halin kimlik edinme sürecinde birleşmesi olarak kullanmıştır (aktaran Özdemir, 2020, s. 14). Bu çalışmada örneklemin genç yetişkinler olarak daraltılmasında temel neden: hayata atılma anlamında önemli bir dönem olan genç yetişkinliği, bireylerin 
icra ettikleri sokak müziği ile geliştirdikleri iletişimsel eylemleri üzerinden okumaktır. Sokak müziğinin yarattığı etkileşimleri irdeleyen bu çalışma, sokak müziği performansının onu icra eden genç yetişkinlerin iletişimsel eylemlerinde nasıl rol oynadığını çalışmanın sac ayağını oluşturan: performe eden-dinleyici, performe edenler arası ve performe eden-yakın çevresi iletişimsel eylemlere odaklanarak keşfetmeyi amaçlamaktadır.

Bu çalışma toplamda altı bölümden oluşmaktadır. Literatür taraması ve çaıışmanın amacını içeren giriş bölümünün ardından gelen ikinci bölümde, sokak müziği bir performans sanatı olarak ele alınmış, burada Victor Turner ve Richard Schechner'in performans sanatı tanımları ile birlikte geçiş/eşik ritüeli tanımlamaları sokak müziği bağlamında ele alınmıştır. Üçüncü bölümde sokak müziği, müziğin diliyle gelişen etkileşimlere odaklanılması amacıyla Habermas'ın iletişimsel eylem ve müzakere etiği yaklaşımları bağlamında okunmuştur. Yöntem bölümü olan dördüncü bölümde, çalışmanın sac ayağını oluşturan sokak müzisyenlerinin dinleyici ile, diğer sokak müzisyenleri ile ve yakın çevreleri ile iletişimlerini kavramsal/kuramsal çerçeve ile test edecek saha çalışması tanımlanmıştır. Beşinci bölümü, dört genç yetişkinle yapılan derinlemesine görüşmelerden elde edilen bulgular ve bunların kuramsal tartışmalarla betimsel analiz tekniği ile çözümlenmesi oluşturmaktadır. Son olarak altıncı bölümde çalışmanın amaç, yöntem ve bulgularının özeti, bunların önceki literatürle temasa sokularak sunulması, çalışmanın sınırlııkları ve ileri çalışmalara kapı araladığı noktalar belirtilmiştir.

\section{Performans Sanatı Olarak Sokak Müziği}

Schechner'a göre (1973) performans ve sosyal bilimin buluştuğu noktalardan biri: "her türlü bir araya gelişi içerecek şekilde günlük hayatta performans" tanımıdır. Bu anlamda performans, bir araya gelişlerde gerçekleşen etkileşimlerle o eylemin öznesi, nesnesi veya hem özne hem nesnesi olarak icra edilmektedir. Schechner'in bu aktarımı, performans sanatı bağlamında ele alınan sokak müziğinin hem sanatsal hem de iletişimsel yönüne işaret etmektedir. Müzik, performans olarak ele alındığında performansı oluşturan üç temel unsur vardır: "müziğin kendisi, müziği icra eden insanlar ve bu müziği dinleyen kişiler" (Küçükaksoy, 2017, s. 1742). Sokak müziği, birçok karşılaşmanın ve bir araya gelişin olduğu sokakta ve gündelik hayatın sıradanlığında meydana gelişiyle sıradanlığı bozan ancak tekrarıyla bir ritüel haline gelerek sıradanlığa dahil de olan bir olgudur. Schechner performansı, "biçimsel ritüellerin, kamusal bir araya gelişlerin ve bilgi, mal ve gelenek değiş tokuşunun çeşitli biçimlerinin bir parçası olan ya da onlarla devamlılık içerisinde olan bir çeşit iletişimsel davranış" olarak tanımlamaktadır (aktaran Mimesis, 2009, s. 12). Turner ise performans sanatını, "ritüellerin harekete dökülmüş modern örnekleri" olarak tanımlamaktadır (1988, çev. Nutku, s. 7). Bu anlamda, performans sanatı daha çok sahne sanatlarına gönderme yapsa da gösteri sanatlarını da kapsamaktadır ve bir icranın tekrarı -ritüelistik niteliği- söz konusu olduğu için sokak müziği performans sanatı bağlamında ele alınabilir.

Schechner'a göre (2003, s.70) performans, performe edenin icrasına baş- 
ladığı anı, gösteriyi ve bu esnada seyirci ile etkileşimleri ve icranın sonlanışını kapsayan geniş bir süreçtir. Bir süreç olarak ele alınan performans aynı zamanda ikinci kez davranılan davranıştır (performance as twice behaved behavior) (Schencher, 2002, s.33). Bu anlamda performans, daha önceden öğrenilmiş davranışların tekrarı olduğundan deneyimden farklılaşmaktadır. Zira performans, hem tekrarlanan ögeler içerir hem de sadece onu icra edene ait değildir; davranış anında gelişen tüm etkileşimler edimsellik (performativity) sürecine dahil edilmiştir. Bu açıklama, Turner'ın eşik kuramına paralel olarak performe edenin her daim "aradalık" halinde olmasına da işaret etmektedir. Victor Turner, Performans Antropolojisi adlı kitabında, ritüelleri sosyal bilimler ile kesiştirerek sunmaktadır. Ona göre performans, sadece var olan toplumsal kodların bir yansıması değil, toplumun kabul ve dışlamasını da içeren bir olgudur. Turner (1982, s. 92), performans ile paralel olarak geliştirdiği "geçiş/eşik ritüeli" kavramsallaştırmasını üç aşamada ele almaktadır. Illk aşamada bireyler bulundukları toplumsal konumundan ayrılmaktadır. İinci aşamada bu ayrılıştaki geçişi kasteden "eşik" (liminality) kavramı kullanılmıştır. Üçüncü aşamada ise birey artık yeni bir konumda yer almaktadır. Yeniden konumlanışa geçiş/eşik aşamasında arada kalma söz konusu olduğu için birey gündelik hayatta kendini tuhaf ve belirsiz bir konumda hissedebilmektedir. Bu bağlamda, sokak müzisyeni performansı esnasında ne tam anlamıyla müziği duyumsaması ve alımlamasıyla kendisini yansıtır ne de sokak müzisyeni rolünü üstlenerek estetik deneyiminden sıyrılabilir. Bu arada olma durumuyla sokak müzisyeni, yalnızca onun müzik alımlamasına odaklanarak değil; içinde bulunduğu estetik ekolojiyle bütüncül değerlendirilmelidir. Bu doğrultuda, bir performans sanatı olarak sokak müziği, bir tekrarın ürünü olması ve kamusal alanda icrası nedeniyle sadece müzisyene ait olan bir davranış olmadığından sokak müzisyeninin etkileşimlerine odaklanarak ele alındığında anlamlanmaktadır.

\section{İletişimsel Eylem Bağlamında Sokak Müziği}

Insanı doğası gereği toplumsal tanımlayanlardan olan Habermas, kamusal alanı da basit etkileşimlerle ortaya çıkan toplumsal bütünleşmeler olarak görmektedir (Habermas, 2007, s. 135). Burada vurguladığı nokta ise modern kent yaşamında rasyonel bireyin tartışma kültürünün de gelişmiş olmasıdır. Yani kamusal alanlar, soruların herkes tarafından tartışımasına ve uzlaşının sağlanmasına olanak tanıması yönüyle "genel" mekânlardır (Habermas, 2007, ss. 135-136). Habermas, bu uzlaşının sağlanmasında iletişimin rolüne vurgu yapmış, rasyonel bireylerin tartışma düzleminde bir araya gelerek uzlaşmasını iletişimsel eylemleri ile mümkün görmüştür (Habermas, 1996, ss. 859-861). Oldukça kapsamlı bir kavram olan iletişim, hem dilsel süreçleri hem de tümüyle toplumsal etkileşimleri çevrelemektedir. Habermas (1996), toplumun normatif değerlerinin yer aldığı ve iletişimin gerçekleştiği ortamı "yaşantı dünyası" (life-world) olarak adlandırmaktadır. Yaşantı dünyasında bireylerin ortak sonuca varmak adına birbirleriyle iletişimi aslında toplumun sistemli yapısını da oluşturmaktadır. Bu bağlamda kamusal alanlar, iletişim ile bireylerin uzlaşmaya yanaşacakları ve bunun için dili araç edindikleri mekânlardır. Bu yönüyle sokaklar, hem toplumsal bir aradalığın sağlandığı kamu- 
sal alanlardır, hem de birçok etkileşimi barındıran tartışma ve uzlaşı mekânlarıdır. Buralarda sergilenen müzik icrası, müziğin araç olduğu bir iletişimsel eylemdir. Kentin karmaşası içinde birbirini tanımayan onca insanın rast gele karşılaşmalarında müzik, müzisyen ile onu alımlayanlar arasındaki iletişimde dil olmaktadır.

Kenti mekânsal bir birim olarak kabul eden Lefebvre'e göre kent, "çatışmadan azade ahenkli bir mekân olmamasına rağmen, yenilikçi ve esnek bir yapıya sahiptir" (Lefebvre, 1996). Bu bağlamda, gündelik yaşamın tüm derinlikleri ve karmaşası kente yansımaktadır. Sokak müziği ise hem gündelik hayatın karmaşasına şahittir hem de müziğin dili ile sağladığı iletişim, kent hayatında ahenge olanak vermektedir. Zira Habermas, toplumların gelişimini yaşam dünyalarında bazı sorunların doğmasına izin vermek olarak görmektedir (Habermas, 1996, s. 861). Burada "sorunlar" kentin karmaşasını da içeren farklıııklar olarak genellenebilir. Bu farklııklar, bireylerin kamusal alandaki her türlü eylemlerini şekillendirdiğinden bu noktada Habermas'ın iletişimsel eylem kuramı ile yapmış olduğu açıklamalar anlam ifade etmektedir.

Iletişimsel eylem kuramı, bireyin eylemlerini; "araçsal", "stratejik" ve "iletişimsel" rasyonalite eylemleri olarak açıklamıştır. Bireyler, araçsal rasyonalite ile kendi hedeflerini gerçekleştirmek adına yaşam dünyalarına müdahil olmaktadır. Ayrıca bireyler, ötekinin kararına yön vermek ya da etkilemek adına yönettiği stratejik rasyonalite eylemlerine de sahiptir. İletişimsel eylem kuramında müzakere etiği gibi uzlaşıya vurgu yapan sonuçları hedefleyen eylemler ise "iletişimsel rasyonalite" eylemleridir. Burada bireyler iletişimi temele koyarak birbirlerini anlama ve uzlaşma çabası içerisindedir.

Habermas, nitelikli iletişimin sağlanması için özgür ortamın yaratılmasının da altını çizmektedir. Bu anlamda kamusal alanlarda özgürce gerçekleştirilen iletişim, birbirini anlama ve uzlaşıyı mümkün kılmaktadır. Bireyler, birbirini eleştirebilen ve bunu tabii karşılayan "ideal konuşma ortamları"nı yaratarak müzakere etiğine erişebilmektedir. Burada bireylerin iletişimsel eylemlerinin anlaşıIması, bu eylemlerin hitap ettiklerinin yaşam dünyasında anlam bulmasına bağlıdır. Müzik bir iletişim kanalı olarak ele alındığında, onu icra edenin kamusal alanlarda -sokakta- müzik icrası ile, bu süreçte yaratılan iletişim ortamını birçok yönden etkilemektedir.

\section{Yöntem}

Bu çalışmada, genç yetişkin sokak müzisyenlerinin iletişimsel eylemleri etki/sonuç iken, sokak müziği sebeptir ve nedensellik mekanizması etkilerin nedenlerine (causes of effects) -sokak müziğinin nasıl ve neden sokak müzisyenlerinin iletişimsel eylemlerinde rol oynadığına- odaklanılarak kurulmuştur. Örnekleminin dar olması, nedensellik mekanizmasının kuruluş biçimi ve toplanan verilerin değerlendirilmesinde betimsel analiz tekniğine başvurulması nedeniyle bu çalışma bir kalitatif araştırma örneğidir. Veri toplama aşamasında masa başı 
araştırma tekniği olan literatür taramanın yanı sıra, yarı yapılandırılmış derinlemesine görüşme tekniğine başvurulmuştur. Bu doğrultuda bu çalışma, sokak müziği icra eden genç yetişkinlerin iletişimsel eylemlerini müziğin nasıl şekillendirdiğini aydınlatmak amacıyla yürütülen bir keşif çalışması niteliğindedir. Bir kadın üç erkek toplamda dört genç yetişkinle gerçekleştirilen görüşmelerde elde edilen bulgular, "özetlenmiş ve yorumlanmış halinin sunulmasını amaçlayan betimsel analiz tekniği" (Yıldırım ve Şimşek, 2003) ile aktarılmıştır. Betimsel analiz tekniğinin dört temel aşamasına paralel olarak bu çalışmada; bulguların sunulacağı temaları tayin etmek amacıyla araştırma soruları ve kuramsal/kavramsal yaklaşımların oluşturduğu bir çerçevenin belirlenmesi, görüşmelerin bu çerçeve doğrultusunda düzenlenmesi, oluşturulan çerçeveye bağlı kalınarak düzenlenen verilerin yapılan görüşmelerden doğrudan alıntılar eklenerek açıklanması ve son olarak yapılan görüşmeler sonucunda elde edilen bulguların bütüncül biçimde açıklanıp anlamlandırıması aşamaları izlenmiştir.

Victor Turner'ın eşik modellemesi ve Richard Schechner performansa dair yaklaşımları ile birlikte Jürgen Habermas'ın iletişimsel eylem kuramı ve müzakere etiği yaklaşımı bu çalışmanın kuramsal/kavramsal çerçevesini oluşturmaktadır. Bu çerçeve doğrultusunda oluşturulan çalışmanın sac ayağı bağlamında görüşmecilere yöneltilen temel sorular Tablo 1'de aktarılmıştır. 
Tablo 1. Saha Çalışmasının Kuramsal Çerçevesi ve Bağlamı

\begin{tabular}{|c|c|c|}
\hline $\begin{array}{l}\text { Çalışmanın } \\
\text { Kuramsal/ Kavramsal } \\
\text { Çerçevesi }\end{array}$ & $\begin{array}{l}\text { Çalışmanın Sac } \\
\text { Ayağı: İletişimsel } \\
\text { Eylemler }\end{array}$ & Sorular \\
\hline \multirow{3}{*}{$\begin{array}{l}\text { • Habermas'ın } \\
\text { İletişimsel Eylem } \\
\text { Kuramı } \\
\text { • Victor Turner'ın } \\
\text { Eşik ve Performans } \\
\text { Yaklaşımı }\end{array}$} & $\begin{array}{l}\text { Sokak Müziğini } \\
\text { Performe Eden- } \\
\text { Dinleyici Arası }\end{array}$ & $\begin{array}{l}\text { Müzik icrasında, sokaktan geçenler ile } \\
\text { hangi yollarla ve nasıl etkileşime geçi- } \\
\text { yorlar? } \\
\text { Müzik icraları esnasında durup dinleyenler } \\
\text { ile hangi yollarla ve nasıl bir etkileşime } \\
\text { geçiyorlar? } \\
\text { Müzik icralarında sokaktan geçenler ve } \\
\text { durup dinleyenler ile etkileşimde hangi } \\
\text { kelime, jest ya da mimikleri kullanıyorlar? } \\
\text { Sokak müzisyenlerinin performansları } \\
\text { esnasında sokaktan geçenler nasıl tep- } \\
\text { kiler veriyorlar ve müzisyenler ile nasıl } \\
\text { iletişime geçiyorlar? }\end{array}$ \\
\hline & $\begin{array}{l}\text { Sokak Müziğini } \\
\text { Performe Edenler } \\
\text { Arası }\end{array}$ & $\begin{array}{l}\text { Genç yetişkinler sokak müziği icraları es- } \\
\text { nasında diğer sokak müzisyenleriyle nasıl } \\
\text { ve hangi yollarla etkileşime geçiyorlar? } \\
\text { Sokak müzisyenlerinin birbirleri ile ileti- } \\
\text { şimlerinde hangi kelime, jest ya da mi- } \\
\text { mikleri kullanıyorlar? } \\
\text { Sokakta çalan diğer müzisyenlerle soka- } \\
\text { ğın dışında nasıl bir iletişim gelişiyor? }\end{array}$ \\
\hline & $\begin{array}{l}\text { Sokak Müziğini } \\
\text { Performe Eden- } \\
\text { Yakın Çevresi Arası }\end{array}$ & $\begin{array}{l}\text { Genç yetişkinlerin sokak müziği perfor- } \\
\text { mansı; okul hayatı, arkadaş, aile gibi ya- } \\
\text { kın çevreleri ile ilişkisini hangi yollarla ve } \\
\text { nasıl şekillendiriyor? } \\
\text { Müzisyenler, sokak müziği icraları bağla- } \\
\text { mında yakın çevreleri ile nasıl etkileşime } \\
\text { geçiyorlar? } \\
\text { Genç yetişkin müzisyenlerin sokak mü- } \\
\text { ziği performanslarını yakın çevreleri nasıl } \\
\text { karşılıyor, hangi tepkileri veriyor, müzikle- } \\
\text { rini hangi yollarla alımlıyor? }\end{array}$ \\
\hline
\end{tabular}

Görüşmecilere ulaşma sürecinde, yakın çevreden sokak müzisyenlerine görüşme talebi yapılmasının yanı sıra, çalışmanın sac ayaklarından birini oluşturan sokak müzisyenlerinin diğer sokak müzisyenleriyle etkileşimlerini keşfetmek amacıyla, ulaşılan görüşmecinin birlikte çaldığı diğer müzisyene kartopu tekniği ile ulaşılmıştır. Görüşmecilerden Özge (24) Hacettepe Üniversitesi Medya ve Kültürel Çalışmalar Programı yüksek lisans öğrenciyken, grup arkadaşı Ulaş (24) Trento Üniversitesi International Management bölümünde yüksek lisans öğrencisidir. Berkay (24) Başkent Üniversitesi İşletme bölümü mezunu; Mücahit Ali, (23) Kocaeli Üniversitesi Radyo, TV Sinema bölümü lisans öğrencisidir. Görüşmecilerin 
tamamı sokak müziğini öğrenciyken icra etmiş, sokakta müzik icralarının devamlılık süresi çeşitlilik göstermiştir. 2020 ylı Mart ayı itibariyle Türkiye'de de görülmeye başlanan Koronavirüs pandemisi nedeniyle sokakta çalmaya ara vermişlerdir.

Genel anlamda müzik yoluyla geliştirdikleri iletişimi tanımlamak amacıyla; dinleyiciler ve yakın çevrelerinde yer alan aile arkadaş ve eğitim hayatındaki özneler ile müzik yoluyla nasıl bir iletişim geliştirdikleri sorgulanmıştır. Müziğe bakış açıları ve etkileşimlerin bu bakışı nasıl şekillendirdiğine dair genel soruların ardından sokak müziğinin bu etkileşimlerden farkını keşfetmek ve ayırt edici yanlarına ışık tutmak amacıyla görüşmecilere, çalışmanın sac ayağını oluşturan unsurlar doğrultusunda önce sokaktaki ilk müzik icrası deneyimleri; ardından hayatlarında ritüelistik anlam kazanan sokak müziği performanslarına dair sorular yöneltilmiştir. Son olarak, kendi sokak müziği icralarının ve bununla gelişen etkileşimlerin genç yetişkin sokak müzisyenlerinin müzakere etiğini ne yönde etkilediğini keşfetmek amacıyla geldikleri noktayı nasıl değerlendirdikleri ve hayatlarının bundan sonrasında sokak müziğinin yeri sorgulanmıştır.

Görüşmeler, Koronavirüs pandemis nedeniyle yüz yüze gerçekleştirilemediği için görüntülü ve sesli çevrimiçi görüşme programı üzerinden gerçekleştirilmiştir. Her bir görüşme yaklaşık bir saat sürmüş, görüşmeler görüşmecilerin onayının alınmasıyla ses kaydına alınmıştır. Çalışmanın Bulgular bölümünde doğrudan alıntı yapma ve kuramsal tartışma için hatırlatıcı olması amacıyla, görüşmelerin ses kayıtlarının deşifresi yapıımıştır.

\section{Bulgular}

Görüşmecilerin müziği nasıl alımladıklarını keşfetmek amacıyla, müzikle olan ilk temasları, ilk enstrümanlarını alışları ve enstrüman tercihleri ile bunları şekillediren faktörler irdelenmiştir. Farklı aile yapısına ve ekonomik koşula sahip görüşmecilerin tümü müziğe başlamalarını, ailelerinin içinde bulunduğu sınıf ethosu ile bağlantıı olarak aktarmıştır. Görüşmecilerin genel anlamda müzik ile kurdukları iletişim ve müziği dil edinmeleri, lise ve üniversitenin ilk dönemlerinde dahil oldukları enstrüman kursları ile mümkün olmuştur. Görüşmecilerden bazıları bu dönemde enstrüman kurslarına katılmıs, eğitmenlerinin müziğe ısınmada itici güç olduğunu belirtmiştir. Bunun yanı sıra, ilk enstrümanını kendi birikimi ile alıp kendi imkanları ile daha uzun sürede ama tutkuyla enstrüman kullanmayı öğrendiğini belirten de olmuştur. Görüşmeciler, ilk sahne performanslarını gerçekleştirdikleri lise dönemlerinde "farklı" olma hissi ile gelişen sosyalleşmelerinde müziğin olumlu etkisinin olduğunu belirtmiş̧ir.

"O zaman hem ergenliğin stresi hem baskıları hem de masaüstü oyunlara ilgim nedeniyle ailemle çok fazla sorun yaşıyordum. Okulu çok asıyordum, internet kafelerde evde oyunlar oynayan sinirli stresli bir insandım. Sonrasında yeni geçtiğim okulun müzik hocasının ücretsiz gitar dersi verdiğini öğrendim (...) Müzik gerçekten benim için kurtarıcı bir öge oldu (...) Çünkü amacın oluyor, 
arkadaşların vardır sosyal çevren genişler (...) müziğin bana bir çıktı verdiği, farkılış̧mamı sağladığı hem de beni gerçekten rahatlattığını keşfettim." (Berkay, 24)

Bu çalışmanın odağında sokak müziği icrası olduğu için, görüşmecilerden sokak müziği deneyimlerini ayrıntısıyla anlatmaları istenmiştir. Görüşmeciler, kasıtlı bir eylem olmasa da sokakta müzik yapmanın sokaktan geçenleri gözlemlemeye olanak tanıdığından bahsetmiştir. Gözlemleri, sokaktan geçenlerin onlara tepkilerine dair açıklamalar yapabilmelerine fırsat tanımıştır. Bu bağlamda, sokak müziğinin herkese açık ve geçişlerin yoğun olduğu kalabalıklardaki icrası, temel amacı toplumu ve gündelik hayatın dinamiklerini gözlemlemek olmasa da, birçok etkileşimin yer aldığı kamusal alanlarda icra edildiğinden sokak müzisyenini Flaneur ile benzeştirmektedir. Walter Benjamin (2012, s. 92-94) Pasajlar eserinde Flaneur'den kenti tüm ilişkileriyle deneyimleyen, gözlemleyen ve çözümleyen özne olarak bahsetmektedir. Bu anlamda sokak müziği, onu icra edene hem kamusal alanda birçok etkileşimde bulunma hem de kentin gündelik hayatına dair gözlem yapma fırsatı sunmaktadır. Burada sokak müzisyeninin gözlemi, sosyologların gözlem ve dinlemeye dayalı olarak gerçekleştirdiği "duvardaki sinek" (fly on the wall) tekniğindeki gibi dahil olunmadan ve gözlemcinin özne olmadığı bir süreç değil; içinde bulunduğu estetik ekolojiyi iletişimler çerçevesinde duyumsadığı bir süreçtir. Buna paralel olarak kadın görüşmeci (Özge, 24): "Sokakta çalarken hep insanları gözlemleme imkânım oluyordu. Parça sırasında genelde kendimi parçaya bırakmaya çalışıyorum ama etrafımdaki kişileri de gözlemlemeye fırsatım oluyor" demiştir.

Öte yandan müzisyenler her ne kadar sokağın onlara özgürlük alanı yarattığında hem fikir olsalar da, Habermas'ın tahakküm ilişkisini içeren stratejik rasyonalite eylemine paralel olarak sokakta ya da metro altı gibi kamusal alanlarda resmi makamlardan izin alarak müzik icra etmektedirler.

“(...) Metrolarda çaldığın yer için izin belgesi götürmek gerekiyor. Biz onu daha önce almıştık ama her seferinde o kağıdın yanında olması gerekiyor. O belge olmazsa çalınmıyor. Ben mesela Özge'den erken gidiyordum, belge Özge'de olunca kurulmama izin vermiyorlardı. Bu bürokratik şeyler oluyor. Sadece belirlenen duraklarda ve belirlenen saatlerde çalıyorduk. Zamanla duraklar karılıyordu." (Ulaş, 24)

Görüşmeciler sokak müziği performansları boyunca; dinleyenler, diğer müzisyenler ve çevreleri ile müziğin diliyle uzaklaşmalarının iletişimsel eylemlerine katkısının altını çizmiştir. Müzakere anlayışı müzisyenlere sokakta çalmanın hazzını yaşatırken, dinleyicilere ve yakın çevrelerine de müzisyenin estetik deneyimini duyumsama imkânı vermektedir. Bu anlamda görüşmeciler, hem dinleyiciler ve diğer sokak müzisyenleri hem de sokakta çalmaları için izinlerine başvurdukları resmi makamlarla repertuvar belirleme, performans mekânları ve zaman konusunda müzakere yoluna gitmeyi yeğlemektedirler. 


\section{Sokak Müzisyenlerinin Müziği Duyumsamaları}

Görüşmecilerin kendi yaptıkları müziği hissederek alımlamaya aşina oldukları halde ilk sokak deneyimlerinde hissettiklerini aktarış biçimleri, Turner'ın (1982, s. 93) tanımladığı "geçiş/eşik" aşamasında olmalarıyla örtüşmektedir. Sokakta müzik yapmaya karar veren görüşmeciler, bulundukları toplumsal statülerinden ayrılarak sokağa çıkmaktadırlar ve sokaktaki ilk deneyimleri gerek müzisyenler gerek çevreleri için bir eşik aşamasıdır. Sokak müziğinin kamusal alanda icrası nedeniyle özgürleştirici bir etkisinin olduğunu öne süren görüşmecilere göre sokak müziği; gerek müzisyenin estetik deneyimini ve müziği alımlamasını gerekse dinleyici üzerinde bıraktığı duygusal etkiyle onu da bu deneyime dahil edişi nedeniyle bir iletişim kanalı haline dönüşmektedir.
“(...) Ankara'dayken de Budapeşte'deyken de mekânda çaldım ama sokaktaki deneyim bambaşka bir şeydi. Sokakta kurduğum iletişim bambaşka bir şeydi. Aslında Illetişim Fakültesini seçme nedenlerimden biri de bu. Sanat kesinlikle bir iletişim yolu ve bence bu tartışılamayacak bir şey. Illa bir düşünce iletmek değil. İnanılmaz bir duygusal iletişim de söz konusu o yüzden sokak değerli bir alan." (Özge, 24)

Görüşmeciler, sokağın onlara özgüven vererek kendilerini bir kısıtlama altında hissetmeksizin ifade etmelerini sağladığını düşünmektedir. Tamamı belirli mekânlarda ya da organizasyonlarda sahne deneyimi olan görüşmeciler, sokağın bambaşka bir ruhunun olduğunu belirtmiştir. Belirli mekân veya sahneye bağlı çalmanın onları repertuvar seçimi gibi kısıtlamalara tabi tutuşu, yaptıkları müzikten aldıkları zevki azaltırken; bu kısıtlanma hali onları sokakta "kendi müziklerini" çalma özgürlüğüne itmiştir.

"Sokakta çalmanın farkı daha heyecan verici olması çünkü herhangi bir yerde, sahnede çaldığında söylediğinde, arkadaş ortamında çalıp söylediğinde belirli insanlara söylüyorsun, ancak sokakta genel bir akış olduğu için sürekli değişen insanlar var. Bir bakıyorsun 20 yaşında biri de seni dinliyor daha yaşlı bir kadın-erkek de sana bakabiliyor. Birçok farklı insanın sokakta olmasının verdiği etkiyle değişken dinleyici kitlesi ve insanların akışı müziği sokakta yapmayı daha heyecanlı yapıyor diyebilirim." (Mücahit Ali, 23)

"Sokakta çalarken her zaman çok daha rahatsın. Sokakta çalarken her şey sana ait gibi, sadece çalıyorsun dışarda kimse yok gibi. Ama mekânda çalarken 'ya bir hata yaparsam' tereddütü oluyor. Sadece kendinden sorumlu olmuyorsun, iş sahibinin veya dinleyicinin beklentileri oluyor." (Ulaş, 24).

Görüşmeciler, ilk sokak müziği deneyimlerinden de yola çıkarak sokakta müzik icrasına sahne icralarından ayrı bir yerde tutarak ayrıca önem vermektedirler. Farkı müzik zevkine, farklı sınıf ethosuna ve farklı şehirlerde farklı sokak 
deneyimine sahip müzisyenler, müziği duyumsama bağlamında sokağın özgürleşmelerine imkân veren "çıplak" bir alan oluşuyla, müzik performanslarının gelişmesinde iyileştirici bir gücünün olduğunda hemfikirdirler.

\section{Sokak Müzisyenlerinin İletişimsel Eylemleri}

Kuramsal çerçeve doğrultusunda oluşturulan çalışmanın sac ayağı bağlamında, görüşmecilere yöneltilen soruların yanıtları, özetlenerek Tablo 2'de aktarılmıştır.

\section{Tablo 2. Kuramsal Çerçeve ve Bağlamın Bulgular ile Değerlendirilmesi}

\begin{tabular}{|c|c|c|}
\hline $\begin{array}{l}\text { Çalışmanın Kuramsal/ } \\
\text { Kavramsal Çerçevesi }\end{array}$ & $\begin{array}{l}\text { Çalışmanın Sac Ayağı: } \\
\text { illetişimsel Eylemler }\end{array}$ & Bulgular \\
\hline \multirow{3}{*}{$\begin{array}{l}\text { - Habermas'ın Illeti- } \\
\text { şimsel Eylem Kuramı }\end{array}$} & $\begin{array}{l}\text { Sokak Müziğini Per- } \\
\text { forme Eden-Dinleyici } \\
\text { Arası }\end{array}$ & $\begin{array}{l}\text { Geçiş/eşik tanımlamasına paralel olarak toplumsal statüle- } \\
\text { rinden ayrılıp sokakta "müzisyen" kimliğiyle var olan görüş- } \\
\text { meciler, dinleyiciler tarafından kimi zaman kabul gördüklerini } \\
\text { belirten iletişimsel eylemler ile yanıt almış; kimi zaman ise } \\
\text { performansları, dinleyicinin herhangi bir iletişimsel eylemi ile } \\
\text { değerlendirilmemiştir. Dinleyici ile iletişimde müziğin icra edil- } \\
\text { diği mekân etkili olmuştur. Metro altı istasyonları gibi "geçiş" } \\
\text { mekânlarında durup dinleme ve sözlü iletişim eylemi daha } \\
\text { seyrek gerçekleşirken; müziği duyumsadığına dair müzisyene } \\
\text { "iz" bırakmak isteyen dinleyiciler, dil ötesi imgeler ile iletişime } \\
\text { geçmiştir. Çoğunlukla yürüyüş için tercih edilen caddelerde ise } \\
\text { dilin araç olduğu iletişim daha yoğun gerçekleşmiş, dinleyiciler } \\
\text { müzisyenlere yaklaşıp izleyerek dinleme ve performans sonun- } \\
\text { da müzisyen ile sözlü iletişime geçme eylemlerini gerçekleş- } \\
\text { tirmiştir. }\end{array}$ \\
\hline & $\begin{array}{l}\text { Sokak Müziğini Per- } \\
\text { forme Edenler Arası }\end{array}$ & $\begin{array}{l}\text { Turner'ın toplumsal kabul ve dışlanmanın yer aldığı eşik ve per- } \\
\text { formans yaklaşımı doğrultusunda, görüşmeciler sokakta çalan } \\
\text { diğer müzisyenler ve/veya sokakta birlikte çaldıkları müzisyen- } \\
\text { ler tarafından sıklıkla kabul görmüşlerdir. Buna paralel olarak } \\
\text { görüşmeciler, Habermas'ın iletişimsel rasyonalite eylemi yak- } \\
\text { laşımı kapsamında yer alan iletişimin çift taraflı ve müzakere } \\
\text { etıği ile geliştiği; birlikte müzik icra etme, diğer sokak müzis- } \\
\text { yenlerinin performanslarını destekleme, müziğin icra edileceği } \\
\text { alanı seçerken birbirleriyle uzlaşma gibi iletişimsel eylemlerde } \\
\text { bulunmuşlardır. Sokak müziği icrası ile gelişen müzakere etiği, } \\
\text { genç yetişkinlerin sokak dışında da iletişimlerini sürdürmeleri- } \\
\text { ne olanak tanımıştır. }\end{array}$ \\
\hline & $\begin{array}{l}\text { Sokak Müziğini Per- } \\
\text { forme Eden-Yakın } \\
\text { Çevresi Arası }\end{array}$ & $\begin{array}{l}\text { Schechner'in performans tanımından hareketle, görüşmecile- } \\
\text { rin sokaktaki müzik icralarını birden çok kez tekrarlayarak so- } \\
\text { kak müziği icralarına ritüelistik anlam kazandırmaları, sokakta } \\
\text { birçok etkileşime olanak tanıyarak görüşmecilerin özgüvenini } \\
\text { geliştirmiştir. Sokak müziğiyle gelişen iletişimsel eylemlerin } \\
\text { müzakere etiğine katkı sağlamasıyla görüşmecilerin eğitim, } \\
\text { aile ve arkadaşilişkileri olumlu yönde etkilenmiş; sokak müziği, } \\
\text { hayatlarında iyileştirici bir güce sahip olmuştur. } \\
\text { Eşik ve performans yaklaşımı doğrultusunda, bazı görüşmeci- } \\
\text { lerin sokakta müzik icra edişi yakın çevreleri -özellikle aileleri- } \\
\text { tarafından kabul görmemiştir. Bunun yanı sıra, aile ve arkadaş } \\
\text { çevresi tarafından sokakta çalmaları takdirle karşınan görüş- } \\
\text { meciler, yakın çevrelerinin de dinleyici olduğu deneyim akta- } \\
\text { rımları yapmıştır. }\end{array}$ \\
\hline
\end{tabular}




\title{
Performe Eden- Dinleyici Arasındaki İletişim
}

Kentte yürüme eylemi, konuşma eylemi (sözceleme)'ye benzer bir ifade taşımaktadır (De Certeau, 2008, s. 193). Sokaktan geçenler, bir yere yetişme telaşı içinde kent sisteminin parçasını oluşturanlar ya da sadece yürüyüş yapanlar olabilir. Bu anlamda, sokak müziğinin gündelik hayatın sıradanlığını bozma ya da sıradanlığın bir parçası olma hali, sokaktan geçenin onu fark ederek bu fark edişi belirtici bir eylemde bulunması ya da fark etmeden yoluna devam etmesine göre okunabilir. Sokaktan geçenin müziği duyumsadığı an yavaşlaması, durması, müzisyenlere yaklaşarak müziği daha yakından dinlemesi ya da icranın sonunu bekleyip müzisyenle konuşmak istemesi: tümü sokaktan geçeni yaya iken dinleyici konumuna getiren iletişimsel eylemlerdir. Yaya, sahip olduğu dil göstergelerini kimi zaman sahip olduğu anlamlarda, kimi zaman ise anlamından kaydırarak rastlantısal yaratmaktadır (De Certeau, 2008, s. 195).

\begin{abstract}
“(...) bazen duruyorlar şarkının sonuna kadar bekliyorlar 'ne kadar güzel çalıyorsunuz ama benim gitmem lazım' diyerek gidenler oluyor. Bazen para koymaları için açtığımız şeye ufak tefek hediyeler bırakanlar, notlar bırakanlar oluyor. Bu arada ben bazen bunun farkında olmuyorum kendimi çalarken müziğe kaptırdığım için not bıraktıklarını fark etmiyor oluyorum akşam dağılırken görüyordum (...) Mesela 'bugün yanımda bozukluk yok ama sesiniz çok güzeldi' şeklinde not bırakan olmuştu. Parası olmadığı için gofret bırakan ya da şarkının sonuna kadar bekleyip 'yanımda bozuk yok ama şimdi dışardan kestane aldım yer misin?' diyenler de oluyordu (gülüyor)."(Özge, 24)

"Ankara soğuk bir şehirdir hem iklimi hem insanı hem sosyal ortam bakımından. İnsanlar işlerinden çıkar evine koşar. Tam o koşuşturma sırasında yolları Tunalı'dan geçen insanların tepkileri beni çok etkiliyordu. Düşünsene bir insan görüyorsun kafası öne eğik hızlı hızlı evine doğru yürüyor. Tam o sırada müziğimize rastlayıp durup dinlemesi eşlik etmesi bizi çok mutlu ediyordu açıkçası." (Ulaş, 24)
\end{abstract}

Çalışmanın ilk sac ayağını oluşturan sokak müzisyeninin dinleyici ile etkileşimi, "duygulanımsal deneyimi" (Titon'dan aktaran Özdemir, 2020, ss.16-17) yaklaşımıyla örtüşmektedir. Görüşmecilerin sokakta çalarkenki duygularına dair yaptıkları tanımlamalar, onların bireysel estetik deneyimlerine dair bilgi verirken; sokaktan geçenleri veya durup dinleyenleri tanımlamaları ise duygulanımsal deneyim aktarımı bağlamında okunmaktadır. Richard Sennett modern bireyi tanımlarken, duygudaş etkinliklerin yoğunlaştığının altını çizmektedir. Ona göre birey artık "sessiz bir izleyici olarak" sosyal yaşama dahil olmaktadır (Sennett, 1996, s.366).

"Budapeşte'de ilk çaldığımda Türkçe bir parça çalmıştım. Nehir kenarındaydım ve bir sürü insan vardı. Böyle hiçkimse rahatsız etmiyor bu arada, dinliyorlar yakınında duruyorlar. Bazen durup 
bakma olayı vardır ya çok bakmamaya da çalışıyorlar rahatsız etmek istemiyorlar sadece o anı bozmamaya çalışıyorlar sadece dinlemek için yaklaşıyorlar bunu görebiliyorsun. Ve sonrasında şarkıyı bitirdiğimde mesela biri yanıma geldi ve dedi ki : 'çaldığınız şarkının hangi dilde olduğunu ve ne anlattığını bilmiyorum' ama gerçekten beni çok duygulandırdı" dedi. Ağlamaklıydı, çok duygusal bir parçaydı, Simge Pınar'ın Yeni Bir Hayat diye bir parçası var onu çalmıştım. Hiç böyle bir tepki beklememiştim. Tam önümdeydi nehre bakıyordu ama şarkının sonuna kadar bekledi ve bitince yanıma gelip bunu söyledi." (Özge, 24)

Kendi yaptığı müziği alımlama ve o hissi dinleyiciye yansıtma şeklinde bir süreçten geçen sokak müziği performansında; Jeff Todd Titon'un (aktaran Özdemir, 2020, s.16) duygulanımsal deneyim modeline paralel olarak müzisyenin kendi alımlayışının ötesinde, hissin dinleyiciye geçişi mevcuttur. Bu süreçte dinleyici verdiği tepkiler ile duygulanımını sezdirir. Titon'un modellemesindeki bir sonraki aşama olan performansta ise bir davranışın tekrarı söz konusu olacağından "uzlaşılmış beklentiler" mevcuttur. Sokaktan geçenler o caddeden daha önce de geçtiği için sokak müziği yapıldığını biliyordur ya da müzisyenleri ve mekânlardaki meskenlerini artık öğrenmiş, alışmışlardır.

“(...) sokaktan kimse 'aynı zamanda şarkı dinleyeyim' diye geçmiyor. Ancak bazı durumlarda bu rutini bozan şeyler olabiliyor örneğin biri durup 'helal olsun gençler, söyleyin!' deyip para atabiliyor baş selamı verebiliyor ya da başını çevirip bize gülümseyebiliyor. Ama bir başkası orada sadece kendi hayatına odaklanmış -haklı sebepleri vardır- stresli stresli yürüyüp geçiyor, belki duymuyor bile. Insanların ilgilerini çekebilecek bir şey yapmadığın sürece sokaktan çok şey beklememeliyiz." (Mücahit Ali, 23)

Aslında sokak müziği performansı her zaman ilk karşılaşma bağlamında gerçekleşmekte, tekrarlanan ritüeli içermektedir. Michael De Certeau (2008), sokaktan geçme yahut bir yere gitme eylemini şöyle tanımlamaktadır:

“(...) bir yerden geçme etkinliği, bir plan üzerinde bütüncül ve geri dönüşlü bir çizgi oluşturan noktalara dönüştülebilir. Geriye bu planın yansıtıldığı yüzeyin zamansızlığı içine bırakılan kalıntıyı kabullenmek kalır. Görünür olan bu kalıntı, kendisini mümkün kılan operasyonu görünmez kılma etkisine sahiptir. İşte tüm bu belirlemeler, işaretlemeler, sabitlemeler unutma prosedürlerini oluşturur. Bırakılan iz, uygulamanın yerini alır."

(Gündelik Hayatın Keşfi I: Kent İçinde Yürümek, s. 193)

De Certeau'nun değindiği gibi bir yerden geçme eyleminde bırakılan izler, o eylemi anlaşıır kılmaktadır (2008, s.193-194). Bu bağlamda, görüşülen sokak müzisyenleri mekân seçimlerini yaparken insanların sadece gelip geçecekleri ya 
da bir yere yetişme telaşında oldukları için müzisyene iz bırakamayacakları cadde ve meydanların yerine, kendilerini daha görünür ve duyulur kılacak, işlek ve kalabalık ancak insanların yürüyüş yapmak için tercih ettiği caddelerde dinleyicinin izini aramaktadırlar. Ancak De Certeau bu izi coğrafi sisteme ait olmanın yanı sıra sistemi de unutturan olarak tanımlamaktadır (2008, s. 193). Yani, bir yerden geçme eylemi, farklı şekillerde de iz bırakabilmektedir. Bu bağlamda, görüşmecilerden metro altı istasyonunda müzik icra edenler bu icralarını, yürüyüş yapmak için bilhassa tercih edilen Ankara'nın Tunalı Caddesi'nde çaldıkları zamanki "geçişler" ile kıyasladıklarında bir yerden geçme ve iz bırakma hususuna dair farklııkların olduğundan bahsetmiştir. Metro altı duraklarında, cadde ve meydanlara kıyasla geçişler yoğunlukla bir yere yetişme amaçlı gerçekleştiği için oradan geçenler ve müzisyenler arası etkileşim de bu doğrultuda gelişmektedir. Ancak, Ankara'da metro altı durağında müzik performansları esnasında gelişen bir iletişimsel eyleme değinen görüşmecilerin aktardıkları, De Certeau'nun (2008, ss. 194-195) konuşma edimini dahil etmeden yalnızca "iz bırakmaya" dayalı tanımladığı "geçiş" eylemiyle oldukça örtüşmektedir.

"Bir gün orada (Ankara Çayyolu metro altı durağı) çalarken bir kadın geldi, para kutusuna iki çikolata bıraktı, gitti. Bizim için çok olağan bir durumdu, absürt bir şey değildi (...) Biz orada çaldık çaldık en son böyle toparlanma zamanı geldi. Bir baktık hani çikolatalar vardır ya üstünde isim ya da sözcük yazar, kadının koyduğu çikolatalar onlardanmış. İki çikolatayı alt alta koyunca 'susma söyle' yazıyordu. Bu bizi çok ekilemişti. Ve alış veriş merkezine (o metro durağının yakın olduğu avm) girmeden önce kadın bizi fark etmiş, dinlemişti ancak durmamıştı biz bunu sonradan fark ettik. Belli ki alışveriş merkezine girdi, bunları (çikolataları) özellikle seçip almış sonra bize bırakmıştı. Bu paradan çok daha değerli ince bir davranış bunu hiç unutamıyorum." (Ulaş, 24)

Sokak müzisyeni, repertuvar seçimini toplumsal bağlarından ve kültürel kodlarından bağımsız oluşturmamaktadır. Sokak, toplumun farkı birçok kesiminin tezahürü olduğundan; sokak müzisyenleri repertuvarlarını çok çeşitli tutarak "müziğin bir araya getirici" niteliğinden yararlanmaktadırlar (Bennet ve Rogers, 2014, s. 454). Ancak görüşmecilerin tamamı, sokak müzisyenlerinin repertuvar seçimlerini popüler talebe göre şekillendirme tercihlerine eleştirel bakmışladır. Onlara göre sanatçı, ancak özgün müzik yarattığında kendi estetik hazzını karşı tarafa geçirebilmekte ve böylece estetik deneyimini müziğin diliyle dinleyiciye aktarmaktadır. Aksi durumda, yalnızca "dinlenme" kaygısıyla yapılan müzik icrası, müzisyeni sanatçı kimliğini kazandıran "özgün ve farklı olma" durumundan koparmaktadır. Ayrıca, görüşmecilerin hepsinin değindiği ve özellikle ikisinin vurgulayarak eleştirdiği husus olan müzik piyasasında popüler olan parçaları veya milli duygulara hitap edecek marşları -bilhassa İzmir Marşı- sokakta çalan müzisyenler, Habermas'ın stratejik rasyonalite eylemleri kapsamında değerlendirilebilir. Zira, popüler müzik kültürü, tüketici odaklı ve estetik kaygıdan görece yoksun olarak yorumlandığından, müzik piyasasının tahakkümünde bir müzik icrası sunmaktadır. 
"Bir gün yine Eric Clapton çalıyorduk metro altının birinde. Bir kadın geldi ve 'arkadaşlar Eric Clapton burada olsa sizinle gurur duyardı' dedi. Biz de çok iftihar ettik bununla. Çaldığımız parçaları insanların bilmesi ve bu şekilde aktarması bizim için oldukça önemliydi. Çünkü metroda özellikle müzik yapma daha ticari amaca döndü ve insanlar İzmir'in Dağları gibi klasik şeyleri çalıyorlar, insanların milli duygularına hitap etmek için. Biz hiç çizgimizi bozmadık. Her zaman bizim keyif aldığımız ve böylece insanları pozitif etkileyecek müzikleri çaldık." (Ulaş, 24)

Teknolojik gelişmeler müziğin yeniden üretilip satılmasına olanak verdiği için sokak müzisyenleri de bu popülariteden etkilenmiş, bulundukları alt sınıftan bir anlamda kopmuştur (Bennet ve Rogers, 2014, s. 455). Görüşmecilerin sokak müziğine bakış açılarını, diğer müzisyenlerin repertuvar seçimleri ve dinleyicilerin bu seçimlere teveccühü de şekillendirmiştir. Popülerleşme, sokak sanatçılarını sınıflarından kopararak kültür endüstrisinin popüler metaları haline getirmiştir (Bennett ve Rogers, 2014, ss. 455- 456). Rağbet gören parçaların bir rutin şeklinde tekrarlanışını sokağın bir dinamiği olarak görerek buna eleştirel bakan görüşmeciler, dinlenmek uğruna "kendi olma"dan kopuşun -popülerleşmenin- onları sokak müziğinden uzaklaştırdığını belirtmişlerdir. Bu bağlamda aslında diğer sokak müzisyenlerinin popüler repertuvarlarına beğeni gösteren dinleyiciye de eleştirel bakılmıştır.

"Insanlar, müziği de arz-talep meselesi olarak görüyorlar. Ya istediklerini vereceksin ya da insanlar seni görmezden gelecek. 'Müslüm'den Hangimiz Sevmedik' ve 'İzmir Marşı' gibi son dönemde popüler olan şarkıları melodikayla çalma nedeni, insanaların onlara değer vermesi ve müzisyenlerin de insanları o noktalarından yakalamaya çalışmaları (...) Sokak müziğinin bu imajı bir anlamda beni sokaktan uzaklaştırdı. Ayrıca insanların müzik zevkini kolay kolay değiştireceğimi düşünmüyorum ve o yüzden çok istikrarlı şekilde bu durumu devam ettiremedim." (Mücahit Ali, 23)

Titon'un duygulanımsal deneyimi çekirdeğine aldığı Müzik-Kültür Modeli'ne (aktaran Özdemir, 2020, s.16) benzer olarak; bu çalışmada sokak müzisyenlerinin müziği duyumsamasının yanı sıra Model'in duygulanımsal deneyimden hemen sonra gelen performans bağlamında icra ettikleri müziğe bütüncül bir bakış sergilenmiştir. Bu anlamda görüşmeciler, sokak müziğini yapma esnasında duygu aktarımlarını "kendi estetik hazlarını önceleyerek" sağladıklarını düşünmektedir. Sokakta çalmanın estetik hazzın göz ardı edildiği anda sürdürülebilir bir konforunun olmadığının altını ısrarla çizen görüşmeciler; sokakta çalmalarındaki yegâne nedenini, sokağın birçok etkileşime sahne oluşuyla performanslarından aldıkları hazzın daha fazla olduğu şeklinde açıklamışlardır.

"Türkiye'de en sık aldığım tepkilerden biri 'neden Türkçe söylemiyorsun?' oluyordu. 'Türkçe çal birkaç tane de Türkçe çal' 


\begin{abstract}
diyorlardı çünkü ben repertuvarıma koymuyordum. Bunu diyen kişiyi kırmamak için çaldığım oluyordu ama benim için önemli olan önce benim o andan aldığım lezzetti ve repertuvarımı yine kendi beğenime ve çalıp söylerken haz aldığım türe göre belirliyordum çünkü benim için önemli olan önce benim keyif almam. Ben zaten haz duyduğum ve hissettiğim sürece bu hissi karşıya geçirebiliyorum o yüzden bunu önecelemeye hep dikkat ettim." (Özge, 24)
\end{abstract}

Görüşmecilerin aktarımlarında genel ifade ile "dinleyici" olarak konumlandırılan "sokaktan geçenler ve durup dinleyenler" üç temel tepkiyle etkileşime dahil olmuştur. Birincisi, sokak müzisyenlerini performansları esnasında gözlemleyip dinleyerek bunu performans sonrası doğrudan iletişime geçerek sözlü iletişime döndüren dinleyiciler; ikincisi, müziği alımlayan ancak bunu performe edene sözlü ifade etmek yerine dil ötesi ögeler aracılığıyla belirten dinleyiciler; son olarak, sokaktan -müziğin icra edildiği kamusal alanlardan- geçerken müziği duyan -ya da duymayan- yalnızca oradan geçip herhangi bir tepki vermeyen dinleyiciler.

\title{
Performe Edenler Arası Illetişim
}

Bennet'e (2014, s. 454) göre müzik farklı birçok zevkin birleşmesiyle bireylere toplumsal bir boyut katmaktadır. Buradan hareketle, müzik onu icra edenler arasında da birbirlerini anlayabilecekleri bir dile dönüşmektedir. Bu dille gelişen anlaşılma hali performe edilen müziği duyumsayanlara da geçmektedir.

“Kocaeli'de Yürüyüş Yolu adında merkezi bir yer var. Bura İzmit'te müzik yapmak isteyenlerin tercih ettiği caddedir. Yani burada başka müzik yapan insanlar da vardı (...) Baktım bu caddede bir çocuk gitar çalıyordu 'sana eşlik edebilir miyim?' dedim, olur dedi ve yanında şarkı söylemeye başladım bir saat şarkı söyledim. Illk deneyimim bu oldu ve o kadar keyif aldım ki bu durum bana yetmedi, aynı gün Yürüyüş Yolu'nda bir abi bağlama çalıyordu ona da aynı şeyi teklif ettim, onunla da şarkı söyledim. İlerde kemençe çalan biri daha vardı ona da teklif ettim ve onunla da Nayino'yu söyledim." (Mücahit Ali, 23)

Habermas'a (1998, s. 598) göre, iletişimin yönü veya çeşidi kadar aracının iki taraf için de "anlamlı" olması gerekmektedir. Bu bağlamda, sokak müzisyenlerinin etkileşimi dinamik tutmak adına, sokağın ruhuna uygun enstrümanlar kullanıp müzik seçimlerini de bu doğrultuda yapmaları müzik diliyle görüş birliğine varmalarını sağlamaktadır.

"Özge'yle benim karakterlerimiz farklı ve istek parçalarımız da farklı. Ben daha çok Elvis Presley parçalarını gitarla çalmayı ve o parçaların enerjisini seviyorum. Özge ise country tarzı parçalardan hoşlanıyordu. Sesinin ön plana çıkabildiği parçaları seçiyordu. O yüzden farklı ses katkıları oluyordu. Farklı gitar ve seslerle çok güzel bir çeşitlilik oluyordu. Daha sonra yumurta tarzı enstrümanlar 
vardır onu, mızıka ve son olarak Özge def ekledi bunlarla sesi de çeşitlendirmeye çalıştık." (Ulaş, 24)

Maddi kaygının ön planda olduğu sokak müziği icrasında bireyler, bilişsel araçsal rasyonaliteye (Habermas, 2007, ss. 176-178) paralel olarak sergilenmiş, yaşamsal olgulara müdahale etmeye yani geçim kaygısını öncelemeye yönelik araçsal eylemler bulunmaktadır. Habermas (1996, s. 862), iletişimsel eylemden bahsederken bireylerin bilişsel-araçsal rasyonalite ile kendi çıkarlarını öncelediklerini ya da tahakküm ilişkilerini içeren stratejik eylemlerine sahip olduklarından bahsetmiştir. Bunun yanı sıra, iletişimsel rasyonalite eylemi ise çift taraflı bir süreci kastederek karşılıklı birbirini anlamayı amaçlayan uzlaşı gayretini ifade etmektedir. Ancak görüşmeciler, maddi kaygıyı önceleyerek sokak müziği icra etmediklerini, sokak şartlarında müzik icrasının ancak bir arada yaşanan tutkuya bağlı sürdürülebileceğini belirtmişlerdir.

\begin{abstract}
"Müzik vasıtasıyla Ulaş'la tanıştık, birlikte müzik yapalım kararına vardık. Farklı kişilerle müzik yapmak çok çok farklı bir şey. Bireyselden çok çok faklı çünkü artık o evrende tek başına değilsiniz yani sizinle birlikte başka enstrümanlar, sesler, kişiler ve onların da deneyimi var. Ben bireysel yaptığım müzikle grup içinde yaptığım müzik arasında ciddi fark görüyorum. Olumlu olumsuz fark diyemem, ikisi de var. Kesinlikle farklı enstrümanların işin içine girmesi daha besleyen, geniş bir deneyim. Bu da daha keyifli oluyor ama bir yandan da şey kaygısı var: uyum sağlayamadığında frekans da kopuyor. Bir şey yanlış giderse iki taraf da keyif alamıyor. Arada bir harmoni yakalamak kargaşayı önlemek çabası oluyor. Ama o uyumu tutturduğun anda harika bir şey. Senin yaşadığın deneyimi o an bir başkasının da yaşıyor olduğunu görüyor olman hazzını ikiye katlıyor diyebilirim. Arada mesela göz teması oluyor bakıyorsun o da mı aynı şeyi hissediyor diye evet o da aynı keyfi alıyor, onu gördügün an o akışı devam ettiriyorduk." (Özge, 24)
\end{abstract}

Yapılan derinlemesine görüşmelerde Ulaş (24) kendi deneyiminin yanı sıra, onu müziği her yerde yapabileceğine ikna eden Ankara Tunalı Caddesi'ndeki performansı esnasında tanıştığı Alman sokak müzisyeni Paul'dan bahsetmiştir. Paul, (18) "hang1" isimli müzik aletini çalarak kazandığı parayla Almanya'dan çıkarak Hindistan'a kadar gitmeyi planlamaktadır. Bu süreçte uğradığı şehirlerin sokaklarında, tıpkı Flaneur'un "en ücra köşelerine kadar metropolü arşınlayıp, modern hayatın bütün görünümünü gözlemlemesi, kalabalıklarda nefes alıp verişi" (Baudelaire, 2013, s.33) gibi hem müzik icra etmekte hem de şehrin insanını gözlemlemektedir.

1 Hang, tamamı çelikten oluşan oval yapıya sahip, üst kısmında içe doğru kavisleri bulunan vurmalı bir enstrümandır. Macarca'da "el" anlamına gelen hang kelimesinin bu enstrümana isim olmasında temel neden; parmaklar ve avuç içi yardımı ile bu çelik yapıya vurularak melodi oluşturulmasıdır. Yere koyularak ya da dizlerin üzerine yerleştirilerek çalınabilen bu enstrüman taşınabilirliği ve farklı sesler çıkarabilmesi nedeniyle sokak müzisyenlerinin de tercihi olmuştur. 


\begin{abstract}
“(...)'nerede kalıyorsun' dedim 'kalacak bir yerim yok insanlar davet ederse onlarla kalıyorum param varsa hostelde kalıyorum' dedi. Ben de 'Kocatepe'de öğrenci evi olan bir arkadaşım var ona gidelim' dedim, beraber gittik. O akşam çok güzeldi. Paul'un enstrümanı var, arkadaşının gitarı var, bende de mızıka vardı. Balkonda soba vardı onu yaktık hafif hava soğuktu, patates attık sobaya. Müzik yapmaya başladık orada. Öyle bir sinerji yakaladık ki, hikayesi enerjisi ve yaşam tarzı o kadar etkiliyor ki o sinerjiyi yakalamamızı. Müzik yaptık eğlendik (...) O gece, doğaçlama Blues müzik yaptığımız bir geceydi." (Ulaş, 24)
\end{abstract}

Müziğin farklılıkları bir araya getirdiğini öne süren Bennet ve Rogers'ın (2014, s. 454) görüşlerine paralel olarak Habermas, iletişimsel rasyonalitesi olan bireylerin uzlaşı yoluyla anlaşmayı sağlayacağına inanmaktadır. Bu doğrultuda, sokak müzisyenlerinin birbirleriyle kurdukları etkileşim, iletişimleri ile gelişmiş ve onların müzakere etmelerine olanak tanımıştır.

“Biz Tunalı'da çalarken orada saksafon çalan bir müzisyenle (16) tanıştık. 'Beraber çalalım mı' diye düşündük. Biz öncesinde atılan para 40-50 TL ise bunda sonra atılanı üçe böleriz dedik, anlaştık. O saksafon çaldı eğlendik, akorları verdi transpoze ettik yani bizim gitarlarınki 'mi'yken onunki 'fa'ydı. Onun çalamadığı notaları biz transpoze ediyorduk. Bir ses benim vokalimde çok şey değiştirebilir yani önemli bir şey. Ama biz uyum sağladık, eğlendik, para kazandık. Oturduk muhabbet ettik. Dedi ki: 'ben şu günler çıkıyorum' biz o günlerde çalmaya başladık." (Berkay, 24)

Turner, bir eylemin ritüelistik anlam kazanması sürecinde kimi zaman kabul gördügünden kimi zamansa dışlandığından bahsetmiştir. Sokak müziği performe eden görüşmeciler, sokakta çalan diğer müzisyenlere bakış açılarıyla onların ritüellerini de tanımlamış, bu tanım da onların diğer sokak müzisyenleri ile etkileşimlerini şekillendirmiştir.

“(...) Benim çaldığım sokakta yıllardır çalan iki kişilik bir grup vardı. Biri görme engelli bir erkekti 6-7 senedir Kocaeli Yürüyüş Yolu'nda hep aynı banka oturarak sokakta çalıyorlar. Biri cümbüş çalıyor biri darbuka çalıyor ve aynı zamanda söylüyor. Aslında söyleyenin sesini duymuyoruz, sadece melodi duyuluyor ve benim onları gözlemlediğim zamanda yani 6-7 yıldır aşağı yukarı hep aynı şeyleri çaldıklarını fark ettim (...) Kendi besteleri mi bilmiyorum, asla ne çaldıklarını bilmiyorum ama inatla onu çalmaya devam ediyorlar ve bunun imzaları haline geldiğini düşünüyorum." (Mücahit Ali, 23)

Sokak müzisyenleri, diğer sokak müzisyenleri ile etkileşiminde ortak dili yakalayıp anlaşarak sanat ürünü verme amacıyla sıklıkla uzlaşmacı tutum sergilemişlerdir. Farklı müzik zevklerine sahip görüşmeciler birlikte çalarken sokakta 
çalacakları şarkıları tartışıp uzaklaşarak belirlemektedirler. Uzlaşı sonucu elde ettikleri ortak ürünlerinin, çeşitliliğin ahengini yansıttı̆̆ından bahsetmişlerdir. Bu eylem de onların müzakere etiği kazanmasına olanak tanımıştır.

\section{Performe Eden ve Çevresi Arasındaki İletişim}

Görüşülen müzisyenlerin tamamı sokak müziğinin onlara başta öz güven kazandırdığını belirtmişlerdir. Bu anlamda, kamusal alanda sergiledikleri performanslarının aile, eğitim ve arkadaş ilişkilerine de yansıdığını, müziğin hayatlarını iyileştirdiğinin altını çizerek aktarmışlardır. Sokakta müzik icrası, birçok insanla etkileşime geçerek sosyalleşmelerine de fırsat vermiş; bu durum onların yakın çevreleri ile ilişkilerini olumlu etkilemiştir.

"Ankara'ya geldiğimde küçük şehirden gelmiş bir gençtim ama girişken bir ruhum vardı önce sokakla başlamadım. Üniversitede birçok kişiyle tanıştım, grup kurduk. Oradaki arkadaşlarım: 'hadi metroda çalalım, sokakta çalalım ne olacak ki?' diyorlardı çünkü geri dönüş bekliyoruz ve orada kazandığın on lira yirmi lira ödül geliyor, maddi gelir boyutunda değildi hiçbir zaman bunu sadece ödül olarak kullanıyordum." (Berkay, 24)

Farklı sınıf ethosuna sahip sokak müzisyenlerinin yöneltilen aynı sorulara "gizli değerler sistemi" kapsamında yanıt verdiği gözlemlenmiştir. Kadın görüşmeci Özge, müziğe başlama şeklini tutkusunu enstrüman alamamanın zaman zaman bastırması üzerinden tanımlarken, Berkay ve Ulaş için enstrüman almaya dair bir sıkıntının yaşanmayışı ilk adımı atma ve sonraki icralarını da etkileyen farklı şeylerin olduğunu göstermektedir.

"Arkadaşlarım yaptığım müziği destekliyorlardı. Hatta bir gün bize sürpriz yapıp yanımıza gelmişlerdi. Dans ettiler, müziğe eşlik ettiler (...) Üniversite hayatım farklı işlerde çalışarak geçti. Bu da bana büyük bir zaman kaybı ve depresyona mal oldu. Ama bütün bunları bırakıp sokak müziğine başladığım zaman, iyileştiğimi hissediyordum diyebilirim. Eve döndüğümde stresten arınmış rahatlamış oluyordum. Sanatın kaygılarımı ve depresyonumu iyileştirdiğini kesinlikle söyleyebilirim." (Ulaş, 24)

Öngen (2020), sokak müzisyeninin günümüze gelen imajını iki farklı şekilde tanımlamaktadır. Sokak müzisyeni bir yandan elverişsiz hayat koşullarında yaşayan ve toplumun en alt sınıfından gelen yoksul gezgin müzisyenler; öte yandan kent devrimi sonrası kent sakinlerinin maddi durumu el verdikçe sokak müziği icra eden halk sanatçısı imajıdır (Öngen, 2020, s.1020). Görüşmecilerden Berkay'ın ilk sokak müziği icralarının akraba çevresince "dilencilik" benzetmesiyle tanımlanması da yine Öngen'in (2020, s. 1020-1021) sokak müzisyeninin imajına dair toplumsal sınıf göndermesiyle yaptığı açıklamayla örtüşmektedir.

"ilk deneyimimde kötü olan şuydu: benim de akrabam sayılabilecek 
biri vardı, görmüş bizi sokakta çalarken. Sonra bizim ailelerimize söylemişti. Ve bizimkiler bana kızdı, 'dilencilik mi yapıyorsunuz, paraya mı ihtiyacınız var?' 'Neden yapıyorsunuz?' çıkışları olmuştu. Öyle bir imaj çizilmişti dilencilik gibi. Müziğe desteklerini hiçbir zaman kesmediler ama sokağı çok uygun görmediler. Ben de sonraki performanslarımdan bahsetmedim. Müziğin hayatımda vazgeçilmez olduğunu gördükten sonra onlar da karışmadı." (Berkay, 24)

Victor Turner, Performans Antropolojisi kitabında, ritüelleri sosyal bilimler ile kesiştirerek sunmaktadır. Turner (1988, çev. Nutku, s. 7) performansı, toplumsal kabul ve dışlama süreçlerini içeren bir olgu olarak ele almaktadır. Bu bağlamda, toplumsal kodların bir tezahürü olan sokak müziğinde, performansa bakış açılarıyla toplumun var olan değerlerini görmek mümkündür. Sokaktan geçenlerin müzisyenin önüne koyduğu kutuya para atış eylemi, sokakta yapılan bir müzik icrası karşı̆ığı bu biçimde bir para kazanımı olduğu için "alt sınıfa ait" ya da toplumun çok kabul etmediği şekilde algılanabilmektedir. Elbette bu tüm toplumlarda aynı değildir. Müziği, toplumsal yaşamın adeta bir kurucu aracı olarak gören Adorno'nun (2011) yaklaşımına paralel olarak müziğin egemen sınıftan bağımsız icra edilmediği düşüncesi (Rocconi, 2012, ss. 224-225), sokak müziğini de içinde bulunduğu toplumdan ve güç ilişkilerinden bağımsız görmemeye dayanmaktadır. Sokaktan geçen türlü türlü insanın ruhuna dokunmak amacıyla tamamen bireysel ve özgün müzik icra etme isteği olan Mücahit Ali , kendi estetik hazzını artıran müzik türleriyle duygunun dinleyiciye geçtiğine inanan Özge ve Ulaş'ın yaklaşımları stratejik eylem yaklaşımından uzak daha çok görüş birliğini mümkün kılan iletişimsel rasyonalite yaklaşımına yakındır. Onların seçimleri, "kapitalist milliyetçi" sisteme yani üst yapıya ait popüler müzik ya da milli duygulara hitap edecek marşların tahakkümünden uzaktır. Habermas'ın yaşam dünyası olarak aktardığı toplumdaki her türlü iletişim eylemini kapsayarak bireyler arası müzakereyi mümkün kılma durumudur. Sokak, birçok etkileşime imkân tanıyan bir kamusal alan olarak sokak müziği özelinde bireyler arası müzakereye de fırsat tanımaktadır.

\section{Sonuç ve Değerlendirme}

Sokak müziği, gündelik hayatın sıradanlığını bir yandan bozarken bir yandan sıradanlığın bir parçası olduğundan sokağı bir sanat ekolojisine dönüştürmektedir. Temel eğitimin ardından hayat kurma yolunda adım atılan yaşlara tekabül etmesiyle gençlik ve yetişkinliğin özelliklerini bir arada barındıran ve bir anlamda arada kalmış niteliğe de sahip olan genç yetişkinlikte, gündelik hayatta sanatı deneyimlemenin en şeffaf hali olan sokak müziği icrası diğer müzik deneyimlerinden farklı bir anlam taşımaktadır. Sosyalleşme ve müziği duyumsamanın yer aldığı sanatçı/ müzisyen kimliği edinme sürecinde; genç yetişkinlikte sergilenen sokak performansı, farklı birçok etkileşime açık haliyle önem arz etmektedir.

Kentlerde müzik icrası, sahne performanslarının aksine çıplak sesle söylenen şarkıları veya sokağa uygun taşınabilir enstrümanları gerektirmektedir. Bu 
bağlamda, teknolojinin olanaklarıyla sesi yükseltilebilen enstrümanların gelişmesi, sokak müzisyenlerini kentlerin gürültüsü içinde daha görünür kılmıştır (Bennet ve Rogers, 2014, s. 454). Bu durum, kent sisteminde var olan "sokaktakiler" ile etkileşimi kolaylaştırmıştır. Her türlü fikrin ulaşılabilir kılındığı ve tartışmaya açıldığı kamusal alanlar, fikirlerin temsiliyetine olanak tanımaktadır. Böylece, modern tartışma ortamlarının yaratılmasıyla yeni fikirler duyulur ve görülür olmakta, bireyler müzakere etiği kazanmaktadır.

Bu çalışmada, genç yetişkinlerin müzik performanslarını sokağın ruhunun ve sağladığı yoğun etkileşim alanının nasıl şekillendirdiğine odaklanılmıştır. Bu doğrultuda, genç yetişkinlerin sokakta kendilerini daha özgürce ifade etmeleri, onlara hem müziği duyumsamalarında hem de "öteki" ile etkileşimde katkı sağlamıştır. Sokak müzisyeni, özgür bir alanda müziğin diliyle anlaşılır olmayı hedeflerken müziği iletişimsel rasyonalite eylemi olarak sergilemekte; sokakta uyduğu belli kurallar ve bunu çerçeveleyen güçler (ör. zabıta, polis) bağlamında bir tahakküm ilişkisini içeren "stratejik rasyonalite" eylemi sergilemektedir. Kamusal alanlarda hayatın olağan akışı içine dahil olan sokak müziği performansı ile hem sokaktan geçenlerin hem de kendi hayatlarının sıradanlığını bozan müzisyenler, müziği bu özgür sahada daha rahat icra ederek estetik hazlarını artırmışlardır. Ayrıca, sokakta performe edilen müziğin sağladığı iletişim atmosferi; müzisyenin dinleyici, diğer sokak müzisyenleri ve yakın çevresi ile iletişimini de iyileştirici güce sahiptir. Dinleyici ile etkileşim; kamusal alanın kullanım işlevine göre değişkenlik göstermiş, geçiş yerlerinde doğrudan iletişim daha seyrekken dinleyicinin bir yere yetişmek zorunda olmadığı cadde ve sokaklarda müzisyenin müziğini duyumsaması ve bunu müzisyene belirtmesi daha çok gözlemlenmiştir. Sokak müzisyenleri, sokakta çalan diğer müzisyenler ile sokağın ahengini bozmayacak şekilde bir uzlaşı ve uyum içinde iletişimde bulunmuştur. Genç yetişkinlerin sokaktaki müzik performanslarının, yakın çevrelerince garipsendiği ve kabul edilmediği durumlar gerçekleşse de, genel itibariyle sokak müziği genç yetişkinlerin eğitim, aile ve arkadaş ile iletişimini destekleyici bir role sahiptir.

Daha önceki çalışmalar, sokak müzisyenini ait olduğu toplumun kodları bağlamında ele almış (Kozyr, 2014), sınıf ethosu'nun müzik seçimindeki rolünün altını çizmiştir. Sokak müziğini mekâna odaklanarak ele alan çalışmalar, (Malkoç, 2018; Günlü, 2013) müzisyenlerin mekân seçimlerini yine o mekândaki kültürel yapının şekillendirdiği sonucuna varmıştır. Bu çalışma ise sokak müziğini tekrarlanan eylem -performans- bağlamında ele alarak genç yetişkinlerin müziği nasıl alımladıklarını, duygulanımsal deneyimlerini, müziğin dili ile sokaktan geçenler ile nasıl temasa geçtiklerini ve sokak müziğinin yakın çevreleriyle olan ilişkilerini nasıl şekillendirdiğini; onlarla yapılan derinlemesine görüşmeler ile keşfederek alana sokak müziğine iletişim antropolojisi bağlamında yaklaşan bir katkı sağlanmıştır. Görüşmecilerin sokağın tüm özneleri ile iletişimlerinde karşılaştıkları dilsel ifade, jest ya da mimik, sokak performanslarına devam etmeleri adına onlara "susma söyle" demiştir. Farklı fikirde birçok insanın bir araya geldiği sokak, müziğin dahil oluşuyla bir uzlaşı alanına dönüşmüştür. Böylece, müzik performanslarının genç 
yetişkinlerin iletişimsel eylemlerine, müzakere etiği algılarına ve sosyalleşmelerine katkı sağladığı sonucuna varılmıştır.

Bu çalışmanın sınırlılığl; koronavirüs pandemisi nedeniyle saha araştırmasını oluşturan görüşmelerin yüz yüze gerçekleştirilememesi ve antropolojik bir yaklaşım sergilenmesine rağmen çalışmada etnografik gözlem yapılamamasıdır. Illeri çalışmalar, genç yetişkin sokak müzisyenlerinin performanslarını katılımcı gözlemci olacakları bir saha ile müzik icralarını performans yerine ilk kez gerçekleştirme haline vurgu yaparak deneyim bağlamında ele alabilir.

\section{Kaynakça}

Adorno, T. W. (2011) "Kültür Endüstrisi Kültür Yönetimi", İletişim Yayınları, İstanbul. Benjamin, W. (2012), Pasajlar (Çev. Berktay, A.) İstanbul: Illetişim Yayınları.

Bennet, A. and Rogers, I. (2014) "Street Music, Technology and The Urban Soundscape", Continuum, Journal of Media and Cultural Studies.

Bourdieu, P. (1984) "Distinction: A Social Critique of The Judgement of Taste", Harvard University Press, Cambridge.

Brokett, O. (2000), Tiyatro Tarihi I. Ankara: Dost Kitabevi.

De Certeau, M. (2008), Gündelik Hayatın Keşfi I: Eylem, Uygulama, Üretim Sanatları (Çev. Arslan Özcan), Ankara:Dost Kitabevi.

Günlü, A. (2013) Mekân-Müzik Illişkisi Bağlamında İzmir'de Sokak Müziği, Yüksek Lisans Tezi, Dokuz Eylül Üniversitesi.

Habermas, J. (1996) İletişimsel Eylem Kuramı, Çev. Tüzel, M. İstanbul, Kabalcı Yayınevi.

Habermas, J. (2007) "Kamusallığın Yapısal Dönüşümü", Çev. Tanıl Bora ve Mithat Sancar, 6. Baskı, İstanbul: Illetişim Yay.

John David Bloodworth (1975) Communication in the youth counter culture: Music as expression, Central States Speech Journal, 26:4, 304-309

Kozyr, A. (2014), Street musicians: the strategies of mastering the social space of St. Petersburg, Keep it Simple, Make it Fast! An approach to underground music scenes

Küçükaksoy, M. E. (2017). Müziğin Performans Sürecindeki "Sihirli Birliktelik": Müzikal Komünitas . Rast Müzikoloji Dergisi , Cilt 5 Sayı 32017

Lefebvre, H., (1996), Right to the City, In E. Kofman and E. Lebas (Ed.), Writings on Cities, Oxford: Blackwell.

Lefebvre, H., (1991), The Production of Space, Oxford: Blackwell. 
Malkoç, İ. (2018) "Sokak Müzisyenlerin Müzik Yapma Amaçları ve Mekân Seçimleri Arasındaki İlişki: İstanbul Kadıköy Örneği", Online Journal of Music Sciences, ss.6-31.

Mimesis: Richard Schechner; (2009), Performans ve Sosyal Bilimler, sayı:16, s. 82.

Öngen, O. (2020), Müzik-Toplum İlişkisi Bağlamında Sokak Müzisyenliği. Haziran, İill, 70.

Özdemir, M. (2020). Şarkılar Seni Söyler: Gündelik Yaşamda Müzikal Nostalji. Galatasaray Üniversitesi Illetişim Dergisi, (32), 7-31

Rocconi, E. (2012) "The Ancient World in The Cambridge History of Musical Performance", by Colin Lawson and Robin Stowell, Cambridge University Press, New York.

Schechner, R. (1973) "Performans ve Sosyal Bilimler". Çeviren: Pınar Gümüş. Mimesis. 16

Schcner, R. (2002), An Introduction Routledge Classics, London and New York.

Schechner, R. (2003) Performance Theory, Routledge.

Sennett, Richard. (1996). Kamusal İnsanın Çöküşü. Çev. S. Durak ve A. Yılmaz. İstanbul: Ayrıntı Yayınları.

Turner, V. (1982) From Ritual to Theatre: The Human Seriousness of Play, New York: Performing Arts Journal Publications

Turner, V. (1988), The Anthropology of Performance, PAJ Publications, Çev. Zeynep Nutku, New York.

Yıldıım, A, Şimşek H. (2003) Sosyal Bilimlerde Nitel Araştırma Yöntemleri. Ankara: Seçkin Yayınları. 